\title{
Socio-economic aspects of the formation of the affordability of residential real estate
}

\author{
Kristina Chepeleva $^{1}$, Valeriya Pukhova $^{2, *}$, and Ekaterina Kashina $^{2}$ \\ ${ }^{1}$ Krasnoyarsk State Agrarian University, 660049, Mira ave., 90, Krasnoyarsk, Russia \\ ${ }^{2}$ Siberian Federal University, 660041, Svobodnyi ave., 82, Krasnoyarsk, Russia
}

\begin{abstract}
The main definitions of the concepts of "market" and "social" affordability of housing are proposed in the article. Particular attention is paid to the consideration of modern methods of assessing the affordability of residential real estate, described in domestic and foreign literature, and in the official documents. Comparative characteristics of the existing methods, calculations and analysis of the housing affordability coefficient in the regional context on the example of the Krasnoyarsk territory are provided. The results of functioning of the market and social segments of the residential real estate market of the Krasnoyarsk territory are presented. The strategic directions of the regional residential real estate market development, the result of which is to be the improvement of the quality of housing and its affordability for all categories of citizens, are developed in the paper.
\end{abstract}

\section{Introduction}

A possibility to improve living conditions of the population is an indicator of the welfare of the society and a prerequisite for social and economic stability. At the state level, the concept of "affordability of housing" should be considered in the socio-economic aspect, taking into account not only the opportunities for purchasing housing of the required level of comfort, but also for obtaining social housing for certain categories of the population.

Numerous theoretical and applied, foreign and domestic studies of housing affordability for the population are aimed, first of all, at studying the market availability of residential real estate.

The purpose of this study is to analyze the categories of "market" and "social" affordability of residential real estate, to compare modern methods of assessing the affordability of housing on the example of the Krasnoyarsk territory, as well as to elaborate strategic directions for the development of the residential real estate market.

\section{Literature review}

Among the analyzed works on the subject of the research were publications of such authors as O.V. Grushina [1], L.R. Musafina [2], V.M. Paliy [3], E.L. Berezina [4], G.M. Sternik,

* Corresponding author: vvvetrova@ya.ru 
S.G. Sternik, A.A. Apalkov [5], A.N. Krasnopolskaia [6], N.N. Nozdrina, M.M. Minchenko [7], A.B. Gusev [8], S.R. Khachatryan [9], N.Yu. Faerman, N.L. Fedorova, A.N. Kirillov [9], D.K. Prazukina, T.Yu. Ovsiannikova, E. Ellenn, E. Vorzal [10], V.N. Edronova, M.E. Shilov [11], A.V. Cherepovich, S. Kauffman [12], C. Kroll [13], M. Hwang, J. Quigley [14] et al.

Despite the diversity of the author's approaches to formulating the category of housing affordability, most of the common definitions do not meet the objectives of the Russia's housing policy, the strategic goal of which is to ensure the availability of housing for all categories of citizens, and not just for the people with average incomes.

In course of the study it was identified that the formation of commercial (market) and social housing is based on different concepts of meeting housing needs [15]. If for the residential real estate market the need is the unsatisfied payment demand for residential properties of a certain consumer quality, confirmed by the purchasing power, for social housing an important parameter is as the ability of less well-off households to improve housing conditions that are lower than existing housing standards.

In accordance with different needs of the income groups of the population, the following segments of the residential property market are distinguished:

- The market segment;

- The social segment [16].

The foregoing determines the following interpretation of the concepts within the framework of the research:

The market affordability of housing is the ability of the household to pay on different conditions the cost of the acquired residential real estate object, chosen in accordance with the required quality and comfort parameters.

The social affordability of housing is the opportunity to improve housing conditions for different strata of the population, to obtain housing corresponding to the minimal modern notions of comfort on a social employment basis and at an acceptable time, where the provided living expenses constitute a reasonable share of income.

In Russia, in the current circumstances, the affordability of housing should be filled not only with economic, but also with social content.

\section{Methods applied}

In economic studies, there are many approaches of the Russian and foreign specialists applied to the market assessment of the affordability of housing.

The most widespread methods for calculating the housing affordability coefficient are compared the in the Table 1.

Table 1. Comparison of the methods of calculation of the housing affordability factor (compiled by the authors on the basis of [17] for the Krasnoyarsk territory).

\begin{tabular}{|l|l|c|c|c|c|}
\hline Name & \multicolumn{1}{|c|}{$\begin{array}{c}\text { FACTORS } \\
\text { CONSIDERED }\end{array}$} & $\begin{array}{c}\text { Year } \\
\text { of } \\
\text { develo } \\
\text { pment }\end{array}$ & $\begin{array}{c}\text { Factor } \\
\text { value for } \\
\mathbf{2 0 1 4}\end{array}$ & $\begin{array}{c}\text { Factor } \\
\text { value for } \\
\mathbf{2 0 1 5}\end{array}$ & $\begin{array}{c}\text { Factor } \\
\text { value } \\
\text { for } \\
\mathbf{2 0 1 6}\end{array}$ \\
\hline $\begin{array}{l}\text { 1. The UN } \\
\text { HABITAT }\end{array}$ & $\begin{array}{l}\text { - average market } \\
\text { value of 1 sq. m. of } \\
\text { residential real } \\
\text { estate; } \\
\text { - average per capita } \\
\text { income per year per } \\
\text { 1 family member. }\end{array}$ & 1993 & 3.2 & 2.8 & 3.3 \\
\hline
\end{tabular}




\begin{tabular}{|c|c|c|c|c|c|}
\hline $\begin{array}{l}\text { 2. The } \\
\text { methodology of } \\
\text { S.R. Khachatrian, } \\
\text { N.Yu. Faerman, } \\
\text { N.L. Fedorova, } \\
\text { and A.N. } \\
\text { Kirillova [8] }\end{array}$ & $\begin{array}{l}\text { - financial and } \\
\text { credit instruments } \\
\text { (mortgages) }\end{array}$ & 2000 & 6.1 & 5.8 & 5.5 \\
\hline $\begin{array}{l}\text { 3. The } \\
\text { methodology of } \\
\text { D.K. Prazukin, } \\
\text { T.Yu. } \\
\text { Ovsiannikova, E. } \\
\text { Ellenn, and E. } \\
\text { Vorzal [9] }\end{array}$ & $\begin{array}{l}\text { - indicator of the } \\
\text { duration of the } \\
\text { accumulation } \\
\text { period, taking into } \\
\text { account the costs of } \\
\text { households and } \\
\text { investing the } \\
\text { accumulated funds } \\
\text { into income assets }\end{array}$ & 2001 & 5.63 & 5.84 & 6.48 \\
\hline $\begin{array}{l}4 . \quad \text { The } \\
\text { methodology of } \\
\text { V.N. Edronova } \\
\text { and M.E. Shilov } \\
{[10]}\end{array}$ & $\begin{array}{l}\text { - transaction costs } \\
\text { when making a } \\
\text { transaction through } \\
\text { a mortgage }\end{array}$ & 2008 & 11.46 & 9.79 & 9.13 \\
\hline $\begin{array}{l}\text { 5. The } \\
\text { methodology of } \\
\text { G.M. Sternik and } \\
\text { A.A. Apalkov [4] }\end{array}$ & $\begin{array}{l}\text { - possibility of } \\
\text { settlements with } \\
\text { and without } \\
\text { mortgages; - class } \\
\text { of housing. }\end{array}$ & 2012 & 5.37 & 5.27 & 4.11 \\
\hline
\end{tabular}

The application of methods for calculating the housing affordability factor, based on the market value and per capita income (the basic methodology), does not allow an adequate assessment of the affordability of housing in the Krasnoyarsk territory for the period under study. On this reason, it is more appropriate to use prototype techniques that tend to become more complex. When making various additions and adjustments in the calculations, the value of the affordability factor of housing shows an increase in 2-4 times, which makes it possible to talk about the real situation with the affordability of housing.

\section{Results}

Based on the analysis of the market and social affordability of residential real estate in the Krasnoyarsk territory, in the Table 2 we present the results of functioning of the market segments.

The results of the analysis of the residential real estate market in the Krasnoyarsk territory (Table 2) indicate that the market segments are not functioning efficiently, in particular:

- On the rental market, the supply exceeds the demand, and illegal rental housing is a fairly common practice. Housing needs are met, but each party has a number of risks as a result of legally unrelated cooperation.

- The segment of non-commercial housing construction is characterized by the lack of demand by people due to the lack of the developed legislative base and financial risks;

- The work of the commercial housing construction segment is connected with distrust of the population to the participants of the shared construction market, the absence of an 
approved classifier of residential real estate that would restricts price speculation and allows determining the amount of property tax by differentiating tax rates for the consumer quality of the property.

Table 2. The results of functioning of the segments of the residential real estate market of the Krasnoyarsk territory for the period of 2013-2017 [compiled by the authors].

\begin{tabular}{|c|c|c|c|}
\hline $\begin{array}{l}\text { Segment of } \\
\text { the market }\end{array}$ & $\begin{array}{l}\text { Strata of people by } \\
\text { the income level }\end{array}$ & $\begin{array}{l}\text { Forms of the state } \\
\text { regulation and } \\
\text { support of people }\end{array}$ & Results of functioning \\
\hline $\begin{array}{l}\text { Social housing } \\
\text { segment } \\
\text { (social } \\
\text { segment) }\end{array}$ & $\begin{array}{l}\text { Poor people in need } \\
\text { of measures of } \\
\text { social support when } \\
\text { hiring municipal } \\
\text { housing }\end{array}$ & $\begin{array}{l}\text { Implementation of } \\
\text { the federal program } \\
\text { "Housing for the } \\
\text { Russian family" }\end{array}$ & $\begin{array}{c}\text { Increase of the } \\
\text { affordability of housing } \\
\text { for certain categories of } \\
\text { people due to: } \\
\text { - decrease of the } \\
\text { average cost per square } \\
\text { meter of housing to } 30- \\
35 \text { thousand rubles / } \\
\text { m2; } \\
\text {-social payments of } 30- \\
40 \% \text { of the value of the } \\
\text { apartment, } \\
\text {-down of the mortgage } \\
\text { rate percentage }\end{array}$ \\
\hline $\begin{array}{l}\text { Hired housing } \\
\text { segment } \\
\text { (market } \\
\text { segment) }\end{array}$ & $\begin{array}{l}\text { People whose } \\
\text { incomes make it } \\
\text { possible to pay for } \\
\text { housing, but do not } \\
\text { allow them to } \\
\text { purchase housing }\end{array}$ & $\begin{array}{l}\text { In fact, there is no } \\
\text { market participants } \\
\text { professionally } \\
\text { engaged in } \\
\text { providing housing } \\
\text { for rent }\end{array}$ & $\begin{array}{l}\text { The current housing } \\
\text { market is mostly illegal }\end{array}$ \\
\hline $\begin{array}{c}\text { Non- } \\
\text { commercial } \\
\text { housing } \\
\text { construction } \\
\text { segment } \\
\text { (cooperative } \\
\text { and individual } \\
\text { construction) } \\
\text { (market } \\
\text { segment) }\end{array}$ & $\begin{array}{l}\text { People whose } \\
\text { incomes make it } \\
\text { possible to build } \\
\text { and acquire housing } \\
\text { in ownership with } \\
\text { the use of } \\
\text { accumulative and } \\
\text { credit mechanisms, } \\
\text { as well as with state } \\
\text { support }\end{array}$ & $\begin{array}{c}\text { Federal and regional } \\
\text { legislation }[19,20, \\
21]\end{array}$ & $\begin{array}{l}\text { Formally it is addressed } \\
\text { to provide a simplified } \\
\text { procedure for the use of } \\
\text { land for construction in } \\
\text { cooperatives. Privileged } \\
\text { categories of citizens } \\
\text { have been established. } \\
\text { However, in practice, } \\
\text { there are a number of } \\
\text { significant difficulties. }\end{array}$ \\
\hline $\begin{array}{l}\text { Commercial } \\
\text { housing }\end{array}$ & $\begin{array}{c}\text { People whose } \\
\text { incomes make it }\end{array}$ & $\begin{array}{l}\text { There are no such } \\
\text { forms (not }\end{array}$ & $\begin{array}{c}\text { Absence of the } \\
\text { approved classifier of }\end{array}$ \\
\hline
\end{tabular}




\begin{tabular}{|c|c|c|c|}
\hline $\begin{array}{c}\text { segment } \\
\text { (market } \\
\text { segment) }\end{array}$ & $\begin{array}{c}\text { possible to purchase } \\
\text { housing without } \\
\text { using state support } \\
\text { mechanisms }\end{array}$ & $\begin{array}{c}\text { stimulated segment } \\
\text { of the housing } \\
\text { market) }\end{array}$ & $\begin{array}{c}\text { housing on the level of } \\
\text { comfort. Insufficient } \\
\text { level of trust of the } \\
\text { population to the } \\
\text { participants of the } \\
\text { shared construction } \\
\text { market. }\end{array}$ \\
& & & $\begin{array}{c}\text { mark } \\
\end{array}$ \\
\end{tabular}

The current state of affairs at the regional level is the consequence of the fragmented solution of the housing problems of the population, and a lack of the integrated approach.

\section{Summary and conclusions}

One of the strategic goals of "The Strategy 2020: A New Growth Model - A New Social Policy" is the formation of social prospects for improving housing conditions for different strata of the population.

Among the most important regional strategic directions, the following ones can be defined:

1. Improvement of regulatory activity in the segment of hired housing.

2. Transition from the management of quantitative indicators to the quality management in the framework of the targeted approach in the field of housing construction.

3. Development of a program of support for the housing non-profit associations of people.

4. Development of a mechanism for the project financing as a part of an alternative to the shared housing construction.

Development of the segments of the residential real estate market, ensuring the increase of both market and social affordability of housing for all categories of the population, regardless of their income, should be the result of the implementation of these strategic directions.

\section{References}

1. O. V. Grushina, Bulletin of the Irkutsk State Economic Academy, 6, 140-146 (2011)

2. L. R. Mustafina, SES, 1(49) (2014)

3. V. M. Paliy, Finance and Credit, 26 (458), 70-74 (2011)

4. E. L. Berezina, Availability of housing in the system of quality of life of the population of the region: socio-economic factors and measurement problems (http://encdic.com/polytech, 2013)

5. G. M. Sternik, S. G. Sternik, A. A. Apalkov, Actual Issues of the Real Estate Market, 2, 31-49 (2014)

6. A. N. Krasnopolskaya, Property Relations in the Russian Federation, 1, 26-38 (2009)

7. M. M. Minchenko, N. N. Nozdrina, Prediction Problems, 2(161), 89-105 (2017)

8. A. B. Gusev, Developing a methodology for assessing the affordability of housing with a loan in Russia (http://realtymarket.ru/docs/pps/gusev1.pdf, 2008)

9. A. N. Kirillova, S. R. Khachatryan, Construction Economics, 9, 9-21 (2000)

10. T. Yu. Ovsyannikova, DK Prazukin, Problems of Economics, 5, 107-112 (2001)

11. V. N. Edronova, M. E. Shilov, Finance and Credit, 31, 18-22 (2008) 
12. S. U. Kauffman, World property channel (http://www.worldpropertychannel.com, 2018)

13. C. A. Kroll, J. Wyant, (Fisher Center for Real Estate and Urban Economics, Haas School of Business, University of California Berkeley, 52 (2009)

14. M. Hwang, J.M. Journal of Regional Science, 2, $42-57$ (2010)

15. V. V. Buzirev, A. O. Berezin, L. R. Mustafina, SES, 1(49) (2014)

16. A long-term strategy of mass housing construction for all categories of citizens (http://geum.ru/next/art-391469.php, 2018)

17. Government of the Krasnoyarsk Territory, Resolution of the Government of the Krasnoyarsk Territory No. 514-P of 30.09.2013 (Krasnoyarsk, 2013)

18. State of the City: urban indicators (http://www.unchs.org/programmes/guo/ guo_guide.asp, 2018)

19. The Federal Law No. 161-FZ of July 24, 2008 (Moscow, 2008).

20. Government of the Krasnoyarsk Territory, Krasnoyarsk Territory Act No. 3-854 (ConsultantPlus, Moscow, 2018)

21. M. Y. Veselovsky, M. A. Izmailova, A. V. Bogoviz, S. V. Lobova, A. N. Alekseev, Quality - Access to Success, 19(162), 60-66 (2018) 